DOI: https://doi.org/10.47405/mjssh.v5i12.565

\begin{tabular}{|c|c|}
\hline & Malaysian Journal of Social Sciences and Humanities (MJSSH) \\
\hline Malaysian Journal of & Volume 5, Issue 12, December 2020 \\
\hline (MJ-sSH) & e-ISSN: 2504-8562 \\
\hline & $\begin{array}{l}\text { Journal home page: } \\
\text { www.msocialsciences.com }\end{array}$ \\
\hline
\end{tabular}

\title{
Persepsi dalam Penggunaan Flipped Classroom dalam Pengajaran dan Pemudahcaraan (Pdpc): Sorotan Literatur Bersistematik
}

\author{
Liew Pei Hong1, Mohd Effendi@Ewen Mohd Matora1 \\ ${ }^{1}$ Fakulti Pendidikan, Universiti Kebangsaan Malaysia (UKM) \\ Correspondence: Mohd Effendi @ Ewen Mohd Matora (effendi@ukm.edu.my)
}

\begin{abstract}
Abstrak
Tujuan artikel ini adalah untuk mengetahui penggunaan flipped classroom dalam pembelajaran dan pemudahcaraan (Pdpc) dalam tempoh 2016 hingga 2020. Satu kajian ulasan sistematik telah dijalankan untuk mendapatkan maklumat yang berkaitan dengan tajuk yang hendak dikaji dengan menggunakan pangkalan data dalam talian seperti ERIC (Education Research and Information), PQDT Online (ProQuest Dissertations and Theses Copyright), Science Direct dan MYTO. Terdapat beberapa kata kunci digunakan iaitu "flipped classroom", "flipped classroom AND perception" dan "inverted learning" untuk mencari kajian yang berkaitan dengan tajuk melalui enjin carian dalam talian. Kajian yang dicari hanya untuk subjek matematik sahaja. Keputusan kajian mendapati penulisan yang berkaitan dari pelbagai negara seperti United Kingdom, Australia, Turki, Korea, China dan Malaysia. Manakala, fokus utama dalam menjalankan ulasan persepsi dalam penggunaan flipped classroom ini adalah mengenal pasti persepsi dari segi kemahiran, pengetahuan dan sikap. Dapatan kajian turut mendapati bahawa kemahiran dalam sifat persepsi pengguna flipped classroom aspek utama yang dikaji oleh penyelidik. Analisis yang dijalankan menggunakan 30 artikel kajian literatur secara menyeluruh menunjukkan hubungan yang positif antara persepsi dengan sifat-sifat penggunaan flipped classroom.
\end{abstract}

Kata kunci: flipped classroom, ulasan sistematik, persepsi, kelas berbalik, matematik

\section{Perceptions in the use of Flipped Classrooms in Teaching and Tacilitation (Pdpc): Systematic Literature Review}

\begin{abstract}
The article is to find out the use of flipped classroom during learning and facilitation in school in the period of year 2016 until 2020. A Systematic Literature Review (SLR) study was conducted to obtain information related to the topic to be studied using online databases such as ERIC (Education Research and Information), PQDT Online (ProQuest Dissertations and Theses Copyright), Science Direct and Malaysia Theses Online. There are several key sentences used to find research related to the topic through online search engines such as "flipped classroom", "flipped classroom AND perception" and "inverted learning". The SLR only focus in subject Mathematic. The result of SLR show that the author is from United Kingdom, Australia, Turkey, Korea, China and Malaysia. Meanwhile, the major focus is conducting perceptual reviews in the use of this flipped classroom to identify perceptions in terms of skills, knowledge and attitudes. The findings of the study also found that the perceived in use of flipped classroom is the main concern studied by researchers. The analysis is using 30 articles and it showed a positive relationship between perceptions with the properties of flipped classroom use.
\end{abstract}


Keywords: flipped classroom, SLR, perception, inverted classroom, mathematic

\section{Pengenalan}

Sejak tahun 1998, teknologi mula diperkenalkan dalam kehidupan manusia dan telah membawa banyak perubahan yang baharu dalam seluruh dunia. Sistem pendidikan di seluruh negara semakin menekankan kepada kemahiran dalam kurikulum untuk menghadapi cabaran yang kompleks pada abad ke-21 ini. Pendidikan Malaysia juga melancarkan Pelan Pembangunan Pendidikan Malaysia 2013-2025 bertujuan untuk meningkatkan taraf pendidikan supaya mampu mencapai standard antarabangsa. Antara salah satu matlamat pendidikan Malaysia dalam kurikulum adalah melahirkan murid yang mempunyai kemahiran abad ke-21 dengan memberi fokus kepada kemahiran berfikir serta kemahiran hidup dan kerjaya berteraskan amalan nilai murni berdasarkan Kurikulum Standard Sekolah Menengah (KSSM). Menurut Perdana Menteri, Tun Dr Mahathir Mohamad yang memberikan ucapan hari guru pada tahun 2020, sebuah kerangka pedagogi abad ke-21 untuk generasi digital diperkenalkan dengan mengandungi lapan komponen utama iaitu pembelajaran kolaboratif, mengupayakan teknologi, pengembangan kemahiran penyelesaian masalah, pembelajaran berasaskan projek, mengoptimumkan teknologi maklumat dan komunikasi (ICT) sebagai sumber maklumat, menggalakkan amalan refleksi, mengembangkan kemahiran berfikir dan pentaksiran.

Perkembangan teknologi dalam pendidikan merupakan panduan dalam pembelajaran bagi mencapai misi melestarikan sistem pendidikan berkualiti untuk menjana pemikiran pendidikan yang kreatif dan inovatif. Flipped classroom merupakan salah satu kaedah yang sesuai dilaksanakan dalam sistem pendidikan Malaysia kerana merupakan suatu kaedah yang mampu menerapkan kemahiran aras tinggi dalam kalangan pelajar dengan melibatkan teknologi dalam pendidikan. Kaedah flipped classroom ini berteraskan penggunaan teknologi dalam memberikan tugasan, nota dan video kepada pelajar sebagai bahan pembelajaran di luar bilik darjah, manakala perbincangan dan konsep pula akan disediakan di dalam kelas melalui pembelajaran. Dalam perkataan yang lain pula, flipped classroom boleh menggantikan kuliah secara bersemuka, di mana pelajar akan diberikan peluang untuk meneroka bahan-bahan yang di luar bilik darjah melalui klip video dan bacaan. Kemudian, pelajar hanya melakukan amali atau tugasan secara "hand-on" di dalam kelas.

\section{Persepsi dalam penggunaan flipped classroom}

Persepsi merupakan pandangan dan pendirian yang diketahui dari pengetahuan kemudian menjadi segolongan daripada sistem pengetahuan dalam pemikiran seseorang individu. Setiap individu mempunyai pandangan dan pendirian yang berbeza dengan individu lain (Mahmod Nazar, 1995). Hal ini kerana seseorang hanya mempunyai satu pemikiran yang secara menetap atau perasaan dan ianya biasanya cuma dapat dilihat dalam pandangan dan pendirian seseorang. Pandangan dan pendirian yang berbeza akan mewujudkan perasaan menerima atau menolak berdasarkan perilaku positif ataupun negatif dan persepsi juga akan berubah mengikut tahap pengalaman atau pengetahuan. Justeru, persepsi dalam konteks kajian ini merujuk kepada tiga bahagian iaitu tahap pengetahuan, kemahiran dan sikap guru terhadap penggunaan flipped classroom dalam Pdpc ini.

\section{Kajian Semasa}

Kajian ini meneliti sorotan literatur mengenai persepsi terhadap penggunaan flipped classroom dalam Pdpc di sekolah. Tujuan pengkaji adalah untuk melihat dari aspek persepsi, menerangkan hubungan antara pemboleh ubah penglibatan guru dengan keberkesanan serta untuk menggeneralisasikan hasilnya. Oleh sebab kajian lepas telah merangkumi pelbagai jenis pandangan persepsi penggunaan flipped classroom, pengkaji membahagikan persepsi dalam kajian ini kepada tiga aspek yang utama 
iaitu kemahiran, sikap dan pengetahuan. Selain itu, skop kajian ini adalah meninjau dari segi pencapaian dalam akademik, hubungan yang aktif dalam pembelajaran, persekitaran yang kondusif, keberkesanan yang positif.

\section{Ulasan kajian lepas}

Kesemua artikel yang dipilih memenuhi skop perbincangan dan persoalan kajian tinjauan sistematik iaitu untuk mengenal pasti dan menganalisis faktor yang mempengaruhi persepsi dalam penggunaan flipped classroom dalam pencapaian akademik pelajar. Menurut Susan (2017) kemahiran dalam penggunaan teknologi secara jangka masa yang panjang akan menyebabkan guru berasa gelisah. Kaedah flipped classroom merupakan suatu kaedah yang sesuai diaplikasikan dalam Pdpc. Namun, terdapat halangan atau cabaran yang perlu diatasi seperti pengetahuan dalam penggunaan teknologi, sikap serta perlu memastikan pelajar dan guru memiliki akses nternet yang stabil (Mathew, 2020). Hoden B (2017) menerangkan kaedah flipped classroom adalah gaya pembelajaran yang sesuai dengan abad ke-21 dan dapat memenuhi kegunaan pada masa depan dalam apa-apa saja kerjaya profesion mengembangkan kemahiran insaniah.

\section{Metod Kajian}

Kajian sorotan literatur melibatkan proses mengumpul, mengenal pasti, menganalisis, merumus serta membuat penilai secara kritikal terhadap isu yang ingin dikaji (Hazari et al., 2017). Menurut Siddiqi et al (2016) SLR bagi melihat dengan jelas fenomena yang berlaku di sekitar. Dalam kajian ini kata kunci "flipped classroom" telah digunakan bagi mendapatkan data kajian.

\section{Strategi pencarian}

Terdapat empat pangkalan data yang berbeza digunakan sebagai sumber pencarian artikel iaitu ERIC, Science direct, $P Q D T$ dan MYTO. Untuk mendapatkan artikel yang berkaitan, pengkaji telah mencari kesemua artikel pada setiap pangkalan data yang disenaraikan. Pencarian dilakukan dengan menggunakan kata kunci yang ditetapkan seperti berikut iaitu "flipped classroom", "flipped classroom AND perception" dan "inverted learning".

\section{Kriteria penerimaan}

Kriteria penerimaan artikel adalah kajian empirikal yang berkaitan dengan persepsi dalam penggunaan flipped classroom bagi subjek matematik dalam proses pengajaran dan pembelajaran. Tahun penerbitan bagi artikel yang dipilih dalam tempoh 2016 hingga 2020. Selain itu, artikel yang akan diterima adalah jenis bahan-bahan artikel dan persidangan. Bahasa artikel yang digunakan hanya bahasa Inggeris dan bahasa Melayu sahaja.

\section{Kriteria penolakan}

Kriteria penolakan artikel adalah kajian yang tanpa bukti empirikal dan artikel yang tidak berkaitan dengan kehendak tajuk yang dicari. Tahun artikel yang sebelum tahun 2016 tidak akan diterima apabila membuat pemilihan artikel. Seterusnya, artikel yang akan tidak akan diterima adalah prosiding buku, sorotan kajian dan sebagainya. Bahasa yang selain daripada bahasa Melayu dan bahasa Inggeris juga tidak akan diterima.

\section{Pengekstrakandata}

Bagi mengelakkan ralat yang berlaku, pengkaji perlu memastikan artikel yang dipilih adalah memenuhi syarat-syarat dan kriteria-kriteria seperti yang telah dijelaskan di atas. Kaedah pengekodan dilakukan bagi setiap artikel yang relevan dan berkaitan dengan menggunakan beberapa parameter 
seperti reka bentuk kajian, kemahiran bukan teknikal yang diukur, kaedah ulasan yang digunakan dan dapatan kajian.

\section{Proses pemilihan artikel}

Untuk melaksanakan tinjauan sistematik ini, pengkaji telah merujuk tinjauan sistematik yang dicadangkan oleh Khan, Kunz, Kleijnen \& Antes, (2003). Terdapat lima peringkat yang digunakan dalam proses pemilihan artikel dan diilustrasikan dalam Rajah 1:

Rajah 1: Langkah-langkah Tinjauan Literatur Sistematik

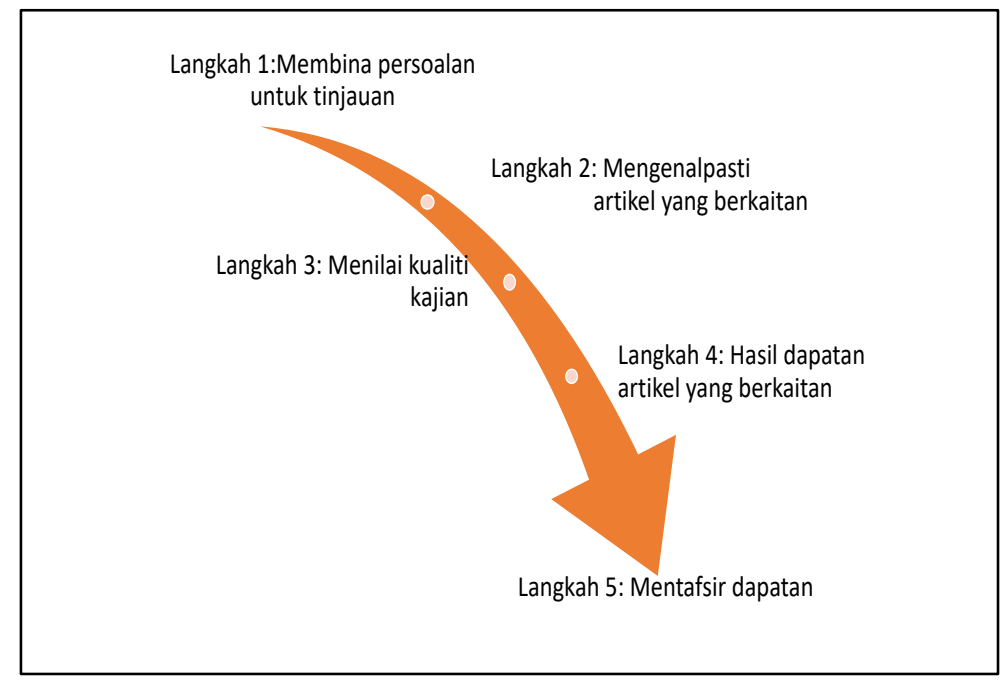

Sumber: Khan, Kunz, Kleijnen \& Antes (2003)

a) Membina persoalan untuk tinjauan (Construct the question for a review)

Persoalan kajian perlu dibentuk sebelum menjalankan tinjauan sistematik. Bagi tinjauan yang dijalankan terdapat satu persoalan sahaja iaitu untuk melihat persepsi dalam penggunaan flipped classroom. Dalam kajian ini, persepsi dibahagikan kepada tiga aspek yang utama iaitu kemahiran, pengetahuan dan sikap.

b) Mengenal pasti artikel yang berkaitan (Identify the relevant work)

Fasa ini pula, artikel jurnal yang dikumpulkan berkaitan dengan tujuan kajian ditapis berdasarkan syarat-syarat yang telah ditetapkan. Setelah membuat tapisan yang lebih lanjut maka artikel yang tinggal itu akan dianalisis. Untuk mencari artikel yang memenuhi kriteria kajian ini, pengkaji telah menggunakan empat enjin pencarian iaitu ERIC (Education Resources Information Center), ScienceDirect, ProQuest Dissertations \& Theses dan Malaysian Theses Online (MYTO). Pengkaji telah mencari artikel yang diterbitkan antara tahun 2016 hingga tahun 2020. Bahasa pengantara yang digunakan adalah dual language berasakan persepsi dalam penggunaan flipped classroom, perception in flipped classroom yang mempunyai teks penuh (full text article) dan responden yang dikaji adalah dalam kalangan guru, pelajar dan pensyarah. Namun, untuk lebih mudah pencarian artikel yang berkaitan dalam pangkalan data, terdapat beberapa kata kunci telah ditetapkan. Antara kata kunci yang ditetapkan merupakan beberapa gabungan kata kunci seperti "perception" AND "flipped classroom" AND "flipped classroom", "effectiveness" AND "flipped classroom", "flipped classroom" AND "education outcome", "flipped learning" dan "perception in flipped classroom". 
c) Menilai kualiti kajian

Terdapat tiga kriteria inklusif akan yang diambil kira dalam tinjauan sistematik iaitu persoalan kajian, metodologi kajian dan dapatan kajian. Tujuan untuk penilaian dilakukan supaya memastikan tinjauan sistematik dapat menjawab persoalan kajian setelah menganalisis artikel-artikel tersebut dan hasil dapatan untuk membuat perbincangan yang lebih lanjut.

d) Hasil dapatan artikel yang berkaitan

Setiap kajian lepas yang diperoleh perlu menyatakan bukti seperti di mana memperoleh artikel tersebut. Bahagian atas telah menerangkan kajian-kajian lepas yang diperoleh daripada lima pangkalan data, maka setelah menjalankan tapisan berdasarkan kriteria yang telah ditetapkan oleh pengkaji, sebanyak 30 artikel yang sesuai digunakan kerana menepati kriteria-kriteria yang ditetapkan (Jadual $1)$.

\section{e) Mentafsir dapatan}

Langkah akhir adalah memperoleh hasil dapatan daripada kajian lepas. Dapatan kajian adalah berdasarkan persoalan yang dibina oleh pengkaji, artikel-artikel kajian lepas yang telah dipilih oleh pengkaji untuk membuat penganalisis dengan menentukan jenis kajian, sampel kajian dan reka bentuk kajian yang digunakan sama ada pendekatan kualitatif, kuantitatif atau kaedah campuran.

Rajah 2: Gambar rajah aliran proses pemilihan artikel

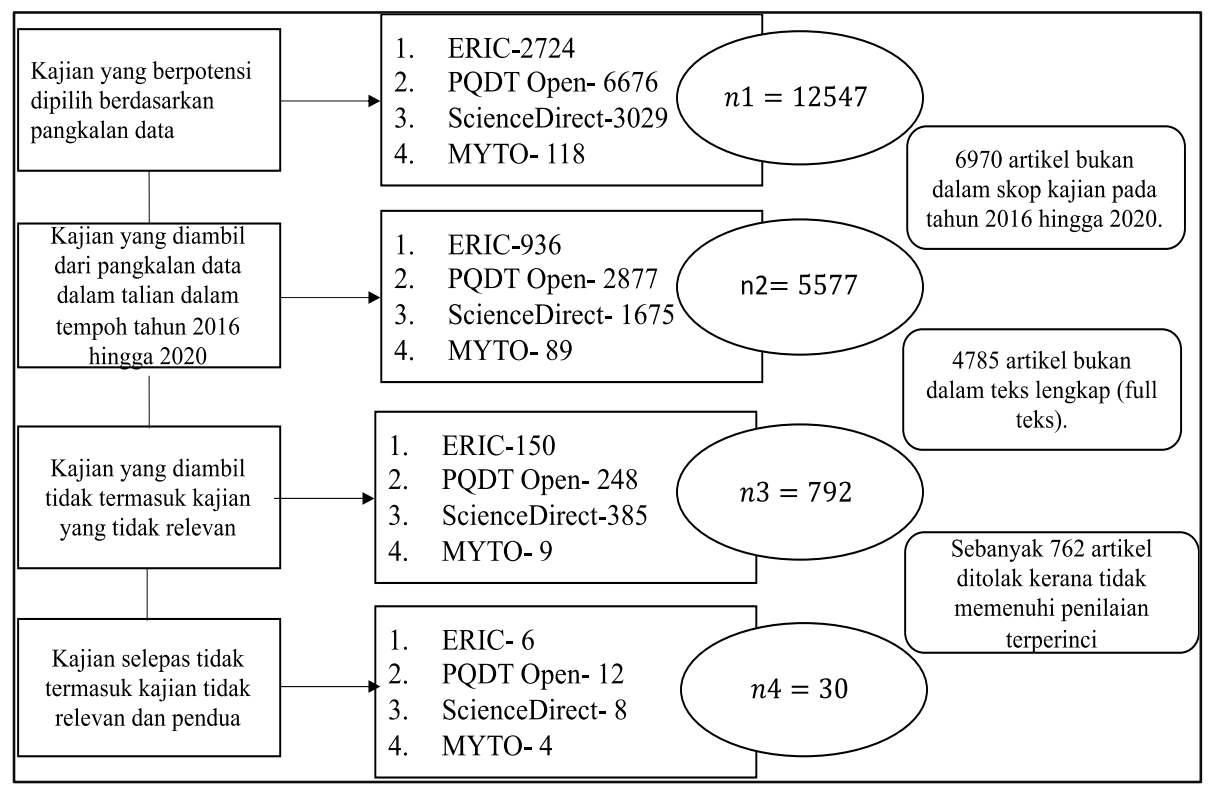

\section{Pengumpulan Data dan analisis data}

Jadual 1: Senarai artikel yang diterbitkan pada tahun 2016, 2017, 2018, 2019 dan 2020

\begin{tabular}{cll}
\hline Bil & \multicolumn{1}{c}{ Penulis } & \multicolumn{1}{c}{ Tajuk } \\
\hline 1 & $\begin{array}{l}\text { Nadeyah Alqallaf } \\
\text { (2016) }\end{array}$ & $\begin{array}{l}\text { Mathematical teacher' perception: Mobile learning and } \\
\text { constructing 21 th century collaborative cloud-computing } \\
\text { environment in elementary public schools in the state of Kuwait }\end{array}$ \\
2 & $\begin{array}{l}\text { Fatimah Hussain } \\
\text { Alebrahin (2016) }\end{array}$ & $\begin{array}{l}\text { Flipped Classroom Professional Development with Faculty } \\
\text { Members to Enhance Students' Engagement in Higher Education }\end{array}$ \\
3 & Jennifer E. & Flipped classroom, as an experiential learning strategy: how do \\
\hline
\end{tabular}


DOI: https://doi.org/10.47405/mjssh.v5i12.565

\begin{tabular}{|c|c|c|}
\hline & Broderick (2016) & faculty adapt to teaching with instructional technology? \\
\hline 4 & $\begin{array}{l}\text { Jenna Van Sickle } \\
(2016)\end{array}$ & $\begin{array}{l}\text { Discrepancies between student perception and achievement } \\
\text { learning outcomes in a flipped classroom }\end{array}$ \\
\hline 5 & $\begin{array}{l}\text { Semih Caliskan, } \\
\text { Huseyin Bicen } \\
\text { (2016) }\end{array}$ & $\begin{array}{l}\text { Determining the perception of teacher candidates on the } \\
\text { effectiveness of MOODLE used in flipped education }\end{array}$ \\
\hline 6 & $\begin{array}{l}\text { Ilknur Ozpinar, } \\
\text { Arzu Aydogan }\end{array}$ & $\begin{array}{l}\text { An application of flipped classroom method in the instructional } \\
\text { technologies and material development course }\end{array}$ \\
\hline & $\begin{array}{l}\text { Yenmez, Semirhan } \\
\text { G(2016) }\end{array}$ & \\
\hline 7 & $\begin{array}{l}\text { Zamzami Zainuddin } \\
\& \text { Mohammad } \\
\text { Attaran (2016) }\end{array}$ & Malaysia students' perceptions of flipped classroom: a case study \\
\hline 8 & $\begin{array}{l}\text { Susan B. Miller } \\
(2017)\end{array}$ & $\begin{array}{l}\text { Teachers' use of instructional moves during technology-based } \\
\text { mathematical activities }\end{array}$ \\
\hline 9 & $\begin{array}{l}\text { Steven Kary Sharp } \\
\text { (2017) }\end{array}$ & $\begin{array}{l}\text { Ipads In the Second Langauge Classroom: An Examination of } \\
\text { Ipad Use By Teachers Through Tpack And Teacher Perception } \\
\text { Lenses. }\end{array}$ \\
\hline 10 & $\begin{array}{l}\text { De Araujo, Z., } \\
\text { Otten, S., \& Birisci, } \\
\text { S. }(2017 \mathrm{c})\end{array}$ & $\begin{array}{l}\text { Teacher-created videos in a flipped } \\
\text { mathematics class: Digital curriculum or lesson enactments? }\end{array}$ \\
\hline 11 & $\begin{array}{l}\text { Rahman A. } \\
\text { Azlina (2017). }\end{array}$ & $\begin{array}{l}\text { Kesan kaedah flipped classroom menerusi pembelajaran } \\
\text { berasaskan projek ke atas pencapaian dan gaya pembelajaran } \\
\text { pelajar }\end{array}$ \\
\hline 12 & $\begin{array}{l}\text { Heather A. Bleecker } \\
\text { (2017) }\end{array}$ & $\begin{array}{l}\text { South Dakota Middle School Mathematics Teachers' perceptions } \\
\text { of teaching }\end{array}$ \\
\hline 13 & $\begin{array}{l}\text { Hoda Baytiyeh } \\
(2017)\end{array}$ & $\begin{array}{l}\text { The flipped classroom model: when technology enhances } \\
\text { professional skills }\end{array}$ \\
\hline 14 & $\begin{array}{l}\text { George R.Buch } \\
(2017)\end{array}$ & $\begin{array}{l}\text { The flipped classroom: Implenting technology to aid in college } \\
\text { mathematics student's Success }\end{array}$ \\
\hline 15 & Jill P. Brown (2017) & $\begin{array}{l}\text { Teachers' persepctives of changes in their practice during a } \\
\text { technology in mathematics education reserach projeck }\end{array}$ \\
\hline 16 & $\begin{array}{l}\text { Stylianos Sergis, } \\
\text { Demetrios G. }\end{array}$ & $\begin{array}{l}\text { Investigating the impact of flipped classroom on student' learning } \\
\text { experiences: A self- determination theory approach }\end{array}$ \\
\hline
\end{tabular}

Sampson, Lina Pelliccione (2017)

17 Azlina A Rahman (2017)

Kesan kaedag flipped classroom menerusi pembelajaran berasaskan projek ke atas pencapaian dan gaya pembelajaran pelajar

18 Robert W. Jaster Student and instructor perceptions of a flipped college algebra (2017) classroom

19 De Araujo, Z., Otten, S., \& Birisci, S. $(2017 b)$

20 Lee, J., Lim, C., \& Kim, H. (2017).

21 Kara Kamphuis (2018)

22 Michael Paul Belanger (2018)

23 Jingying Wang, Min Jou, Yazhong Lv, Chun- Chiang Huang (2018) Mathematics teachers' motivations for, conceptions of, and experiences with flipped instruction.

Development of an instructional design model for flipped learning in higher education Teachers' Perceptions of the Use of AVID in the Math Classroom

Effects of blended learning and gender on Mathematics Assessment in elementary and fifth grade students An investigation on teaching performances of model-based flipping classroom for physics supported by modern teaching technologies

24 Corey Webel, Christina Sheffel \&

Flipping instruction in a fifth grade class: A case of an elementary mathematics specialist 


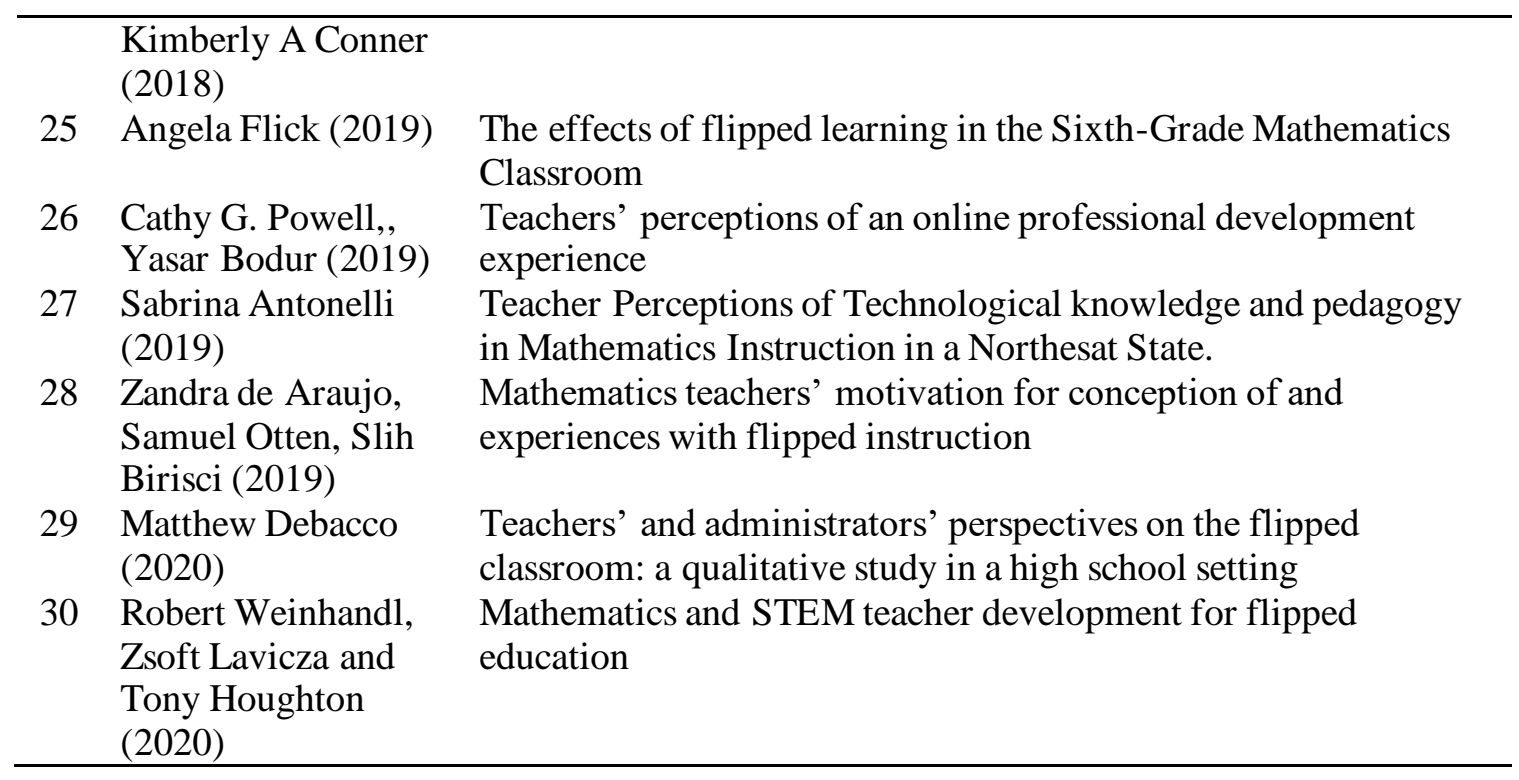

\section{Hasil Kajian}

Objektif utama kajian Sorotan Literatur Bersistematik (SLR) adalah untuk mengenal pasti persepsi dalam penggunaan flipped classroom dalam proses pengajaran dan pembelajaran bagi subjek Matematik. Kajian ini turut membangunkan kerangka konseptual berdasarkan penggunaan flipped classroom yang paling kerap digunakan oleh pengkaji lepas. Hasil penelitian daripada artikel kajian yang lepas terdapat 30 artikel yang menepati semua kriteria. Hal ini demikian telah meringkaskan rumusan mengenai tujuan kajian artikel yang dipilih serta ia akan memberikan gambaran tentang kajian yang dijalankan pada setiap artikel.

Jadual 2: Rumusan mengenai tujuan kajian artikel

\begin{tabular}{|c|c|c|c|}
\hline Bil & Penulis & Negara & Tujuan \\
\hline 1 & $\begin{array}{l}\text { Nadeyah Alqallaf } \\
\text { (2016) }\end{array}$ & US & $\begin{array}{l}\text { Mengkaji persepsi guru matematik terhadap penggunaan } \\
\text { M-learning dalam Pdpc dan cabaran yang dihadapi oleh } \\
\text { guru dalam suasana M-learning. }\end{array}$ \\
\hline 2 & $\begin{array}{l}\text { Fatimah Hussain } \\
\text { Alebrahin }(2016)\end{array}$ & US & $\begin{array}{l}\text { Mengkaji persepsi guru matematik terhadap penggunaan } \\
\text { M-learning dalam Pdpc dan cabaran yang dihadapi oleh } \\
\text { guru dalam suasana M-learning }\end{array}$ \\
\hline 3 & $\begin{array}{l}\text { Jennifer } \quad \text { E. } \\
\text { Broderick (2016) }\end{array}$ & US & $\begin{array}{l}\text { Meneliti dan meneroka persepsi fakulti terhadap teknologi } \\
\text { instruksional yang digunakan dalam flipped classroom. }\end{array}$ \\
\hline 4 & $\begin{array}{l}\text { Jenna Van Sickle } \\
\text { (2016) }\end{array}$ & US & $\begin{array}{l}\text { Mengenal pasti perbezaan antara faktor dan cabaran yang } \\
\text { boleh meningkatkan persepsi pelajar dalam pembelajaran } \\
\text { yang berpusatkan pelajar. }\end{array}$ \\
\hline 5 & $\begin{array}{l}\text { Semih Caliskan, } \\
\text { Huseyin Bicen } \\
\text { (2016) }\end{array}$ & Austria & $\begin{array}{l}\text { Mengkaji persepsi guru dalam kecekapan pelaksanaan } \\
\text { Moodle di persekitaran bilik darjah berdasarkan Remote } \\
\text { flipped }\end{array}$ \\
\hline 6 & $\begin{array}{l}\text { Ilknur Ozpinar, } \\
\text { Arzu Aydogan } \\
\text { Yenmez, } \\
\text { Semirhan G } \\
\text { (2016) }\end{array}$ & Turki & $\begin{array}{l}\text { Mengkaji kesan penggunaan flipped classroom berdasarkan } \\
\text { pencapaian akademik,motivasi dan pendapat pelajar. }\end{array}$ \\
\hline 7 & $\begin{array}{l}\text { Zamzami } \\
\text { Zainuddin \& } \\
\text { Mohammad } \\
\text { Attaran (2016) }\end{array}$ & Malaysia & $\begin{array}{l}\text { Untuk mengkaji persepsi dan maklum balas pelajar } \\
\text { terhadap kelas flipped di sebuah University. }\end{array}$ \\
\hline 8 & Susan B. Miller & US & Mengenal pasti instruksional yang digunakan oleh guru \\
\hline
\end{tabular}


(2017)

9

Steven Kary

Sharp (2017)

10 De Araujo, Z.,

Otten, S., \&

Birisci, S. (2017c)

11 Rahman A.

Azlina (2017).

12 Heather A.

Bleecker (2017)

13 Hoda Baytiyeh, (2017)

14 George R.Buch (2017)

15 Jill P. Brown (2017)

16 Stylianos Sergis, Demetrios G.

Sampson, Lina

Pelliccione (2017)

17 Zandra de

Araujo*, Samuel

Otten, Salih

Birisci (2017)

18 Robert W. Jaster

(2017)

19 De Araujo, Z.,

Otten, S., \&

Birisci, S.

(2017b).

20 Lee, J., Lim, C., Korea \& Kim, $\mathrm{H}$. (2017).

21 Kara Kamphuis (2018)

22 Michael Paul Belanger (2018)

23 Jingying Wang, Min Jou, Yazhong Lv, Chun- Chiang Huang (2018)

24 Corey Webel, Christina Sheffel \& Kimberly A Conner (2018)

25 Angela Flick (2019)

26 Cathy G. Powell, Yasar Bodur
Matematik di mana aktiviti berasaskan teknologi (iaitu, simulasi berorientasikan pelajar) dan ciri-ciri simulasi tersebut mempengaruhi amalan bilik darjah.

US Melihat persepsi guru dalam penggunaan IPAD sebagai media utama dalam proses Pdpc.

USA Melihat kesan penggunaan video dalam pengajaran dan pembelajaran dipengaruhi oleh kurrikulum digital ataupun enakmen pelajaran dalam kalangan guru sekolah.

Malaysia Melihat kesan flipped classroom melalui pembelajaran berasaskan projek untuk memaksimumkan pencapaian pelajar dalam mata pelajaran yang sukar, seperti Matematik.

US South Dakota Middle School Mathematics Teachers' perceptions of teaching

US Mengkaji persepsi guru matematik tentang penggunaan teknologi dalam kaedah pengajaran GPK dan MPCK.

USA Mengenal pasti keberkesanan model flipped classroom dan teknologi dalam proses Pdpc di kalangan pelajar

Australia Melihat perubahan guru dalam tempoh 3 tahuan selepas menggunakan digital teknologi dalam Pdpc.

US Mengenal pasti tahap kepuasan dalam FCM bukan sehaja melibatkan kognitif hasil pelajar malahan melibatkan keperluan untuk kecekapan, autonomi dan hubungan.

US Melihat hubungn antara bahan kurikulum digital dan buku teks dengan menggunakan flipped classroom bagi subjek matematik.

US Meninjau persepsi dalam kalangan instuktor dan pelajar tentang pelaksanaan flipped classroom bagi topik algebra

USA Meneroka tahap motivation, konsep dan pengalaman antara dua guru dalam penggunaan flipped classroom.

US Meninjau persepi guru dalam penggunaan AVID dalam kelas matematik agar dapat pelaksanaan AVID dalam subjek matematik

US Mengenal pasti perbezaan pencapaian dan skor PARCC berdasarkan jantina, gaya pembelajaran dan persepsi dalam kalangan pelajar gred ke $-4 \&$ ke- 5 .

China Mengkaji persepsi Model flipping classroom secara fizikal dengan menggunakan kaedah teknologi dalam proses pengajaran dan pembelajaran

US Mengkaji tahap pengetahuan guru dalam cara menyampaikan flipping instruksion dan cabarannya.

US Mengenal pasti persepsi antara pelajar dengan instuktor dalam flipped algebra di bilik darjah

USA Melihat persepsi guru berdasarkan pengalaman dan kemahiran teknologi dalam proses menyampaikan Pdpc. 


\section{(2019)}

\section{Sabrina Antonelli US} (2019)

\section{8}

Zandra de Araujo, Turki
Samuel Otten,
Slih Birisci
(2019)

29 Matthew Debacco (2020)

\section{Robert}

Weinhandl, Zsoft Lavicza and Tony Houghton (2020)
Mengenal pasti persepsi guru dalam penggunaan teknologi, kandungan pedagogi dan pelaksanaan teknologi bagi subjek matematik.

Mengenal pasti tentang tahap motivasi, persepsi dan kemahiran dalam flipped classroom bagi subjek matematik dalam kalangan dua guru.

Mengkaji persepsi guru dan pihak pentadbir tentang flipped clsssroom di sekolah menengah

Meninjau peranan dan persepsi flipped classroom Approaches (FCA) boleh meningkatkan pencapaian pelajar bagi subjek matematik

Pemilihan artikel dijalankan daripada empat pangkalan data berbeza yang dipilih oleh pengkaji, terdapat sebanyak 12547 artikel yang diperoleh. Terdapat 2724 artikel dari pangkalan data ERIC, 3029 dari pangkalan data Science direct, 6676 artikel dari pangkalan data PQDT open dan 218 artikel dari MYTO. Setelah mengenal pasti skop artikel yang hendak dicari pada tahun 2016 hingga 2020, maka sebanyak 30 artikel telah dipilih.

\section{Lokasi kajian}

Kajian yang dihimpunkan telah diterbitkan di berapa buah negara. Majoriti artikel yang diterbitkan adalah daripada United Kingdom (57\%) dan diikuti dengan negara USA (13\%). Seterusnya, terdapat tiga negara (Australia, Malaysia dan Turki) yang mempunyai bilangan terbitan yang sama iaitu 2 artikel (6\%). Negara China dan Korea pula sebanyak 1 artikel sahaja. Antara artikel yang diterbitkan dari United Kingdom (Matthew Debacco, 2020; Sabrina Antonelli, 2019; Angela Flick, 2019; Michael Paul Belanger, 2018; Steven Kary Sharp, 2017; Jennifer E. Broderick, 2016); Amerika Syarikat (Cathy G. Powell, Yasar Bodur, 2019; De Araujo, Z, Otten, S., \& Birisci, S., 2017c); Turkey (Zandra de Araujo, Samuel Otten, Slih Birisci (2019); China (Jingying Wang, Min Jou, Yazhong Lv, ChunChiang Huang,2018); Australia (Robert Weinhandl, Zsoft Lavicza \& Tony Houghton,2020; Semih Caliskan, Huseyin Bicen, 2016), Korea (Lee, J., Lim, C., \& Kim, H. (2017) dan Malaysia (Azlina A Rahman,2017; Zamzami Zainuddin \& Mohammad Attaran, 2016).

\section{Jenis Instrumen kajian}

Kajian-kajian lepas telah dibahagikan kepada tiga kategori metodologi iaitu kajian kuantitatif, kajian kualitatif dan kajian kaedah campuran. Senarai lengkap kajian lepas berdasarkan ketiga-tiga kategori metodologi ditunjukkan dalam jadual 4. Secara keseluruhannya, hubungan persepsi penggunaan flipped classroom diteliti dari segi kemahiran, pengetahuan dan sikap. Kemahiran dalam konteks kajian ini adalah merujuk kepandaian dalam menguasai perkakasan teknologi dengan mengaplikasikan untuk mengakses maklumat dalam talian. Pengetahuan pula merujuk kepada kefahaman yang sedia ada dalam diri sendiri terhadap penggunaan suatu kaedah yang baru. Sikap dimaksudkan sebagai sikap komitmen, sikap minat dan sikap amanah dalam menggunakan flipped classroom sebagai kaedah pengajaran abad ke-21.

Daripada keseluruhan artikel, didapati para penyelidikan lebih memberi fokus kepada aspek kemahiran iaitu terdapat 17 daripada 30 artikel. Para penyelidikan ingin melihat strategi yang digunakan semasa penggunaan flipped classroom dalam Pdpc. Berdasarkan jadual 4, kebanyakan kajian lepas menggunakan kaedah penyelidikan berbentuk campuran atau gabungan. Kaedah campuran boleh memberikan peluang kepada pengkaji untuk mengetahui sesuatu isu dengan lebih mendalam dan kontekstual. Cara pengumpul data adalah menggunakan set borang soal selidik dan temu duga untuk memperoleh data kajian. 15 daripada 30 iaitu 50\% kajian artikel adalah 
DOI: https://doi.org/10.47405/mjssh.v5i12.565

menggunakan kaedah campuran. Manakala, kaedah kualitatif adalah sebanyak 37\% (11 daripada 30 artikel). Data menunjukkan bahawa kaedah yang paling sedikit digunakan dalam persepsi penggunaan flipped classroom adalah kaedah kuantitatif dengan jumlah 4 daripada 30 artikel. Jelas bahawa, kaedah kuatitatif kurang mampu untuk mentafsirkan secara generalisasi berkenan isu yang hendak dibincangkan.

Jadual 4: Senarai kajian lepas berdasarkan jenis instrumen kajian dan persepsi penggunaan flipped classroom

\begin{tabular}{|c|c|c|c|c|c|c|c|c|c|c|c|c|c|c|c|c|c|c|c|c|c|c|c|c|c|c|c|c|c|c|c|c|}
\hline & \multicolumn{29}{|c|}{ Senarai kajian lepas berdasarkan jenis instrumen kajian dan persepsi penggunaan flipped classroom } & \multirow[b]{2}{*}{ 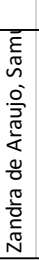 } & & \\
\hline Pengkaji/tahun & 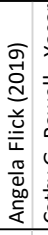 & 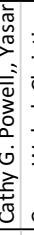 & 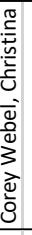 & 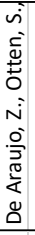 & 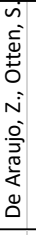 & 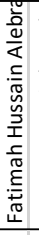 & 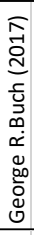 & 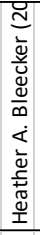 & 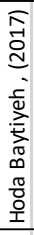 & 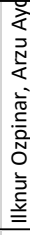 & 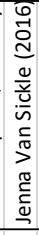 & 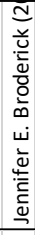 & 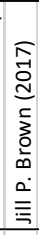 & 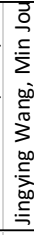 & 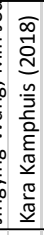 & 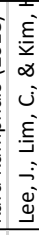 & 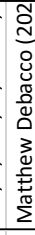 & 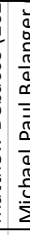 & 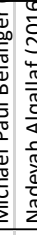 & 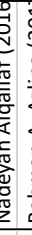 & 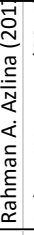 & 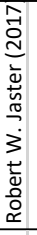 & 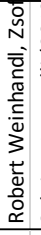 & 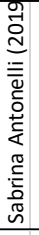 & 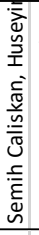 & 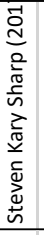 & 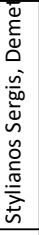 & 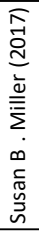 & 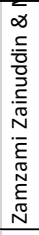 & & 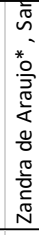 & JUMLAH \\
\hline \multicolumn{33}{|c|}{ Persepsi penggunaan flipped classroom } \\
\hline a) Kemahiran & * & & & & * & & * & & * & & & * & * & & * & * & * & * & * & 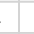 & & * & * & & * & * & * & & & * & & 17 \\
\hline b) Pengetahuan & & * & $*$ & * & & * & & & & & & & & * & & & & & & & & & & * & & & & & & & & 5 \\
\hline iii) Sikap & * & & & & & & & * & & * & * & & & & & & & & & * & * & & & & & & & * & * & & * & 8 \\
\hline & & & & & & & & & & & & & & & & & & & & & & & & & & & & & & & & \\
\hline \multicolumn{33}{|l|}{ Jenis instrumen kajian } \\
\hline i) Kaedah kuantitatif & & & & & & & & * & & & & & * & & & & & * & & & & & & & * & & & & & & & 4 \\
\hline ii) Kaedah kualitatif & * & * & * & * & * & * & & & * & & & & & & * & & * & & & & & & & & & & & * & & * & * & 11 \\
\hline iii) Kaedah campuran & * & & & & & & * & & & * & * & * & & * & & * & & & * & * & 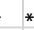 & * & * & * & & * & * & & * & & & 15 \\
\hline & & & & & & & & & & & & & & & & & & & & & & & & & & & & & & & & \\
\hline
\end{tabular}

Data dalam jadual 5 menunjukkan peserta kajian yang terlibat telah dibahagikan kepada empat kumpulan iaitu pelajar, guru, pihak pentadbir dalam sekolah dan pensyarah. Hasil dapatan mencatatkan bahawa populasi majoriti dikaji adalah golongan guru sebanyak 19 artikel (63\%). Seterusnya, tinjauan yang fokus tentang persepsi pelajar (47\%) dan diikuti 3\% iaitu pihak pentadbir di sekolah dan pensyarah. Selain itu, kajian SLR mendapati tidak ada satu artikel penyelidikan yang dilakukan pada peringkat pengajian sekolah rendah dalam tempoh 5 tahun yang terkini iaitu dari tahun 2016 hingga 2020. Kaedah flipped classroom ini yang menumpukan pembelajaran berpusat pelajar lebih sesuai dilakukan pada peringkat sekolah menengah (57\%) dan Universiti (43\%).

Jadual 5: Senarai kajian lepas berdasarkan golongan yang terlibat dan peringkat pengajian

\begin{tabular}{|c|c|c|c|c|c|c|c|c|c|c|c|c|c|c|c|c|c|c|c|c|c|c|c|c|c|c|c|c|c|c|c|}
\hline Pengkaji/tahun & 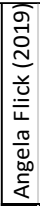 & 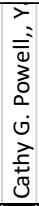 & 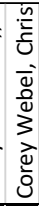 & 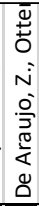 & 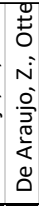 & 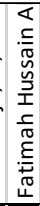 & 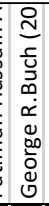 & 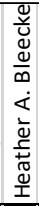 & 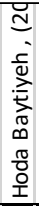 & 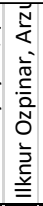 & 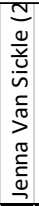 & 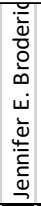 & 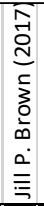 & 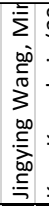 & 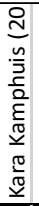 & 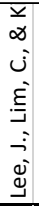 & 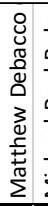 & 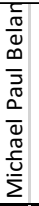 & 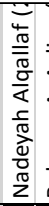 & 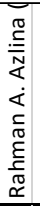 & 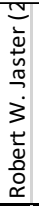 & 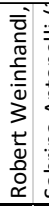 & 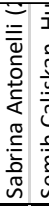 & 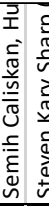 & 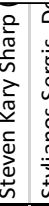 & 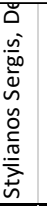 & 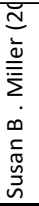 & 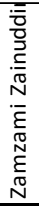 & $\begin{array}{l}0 \\
\frac{0}{3} \\
\frac{\pi}{2} \\
\frac{1}{2} \\
\frac{1}{0} \\
\frac{0}{0} \\
\frac{0}{0} \\
\frac{1}{\pi} \\
N\end{array}$ & 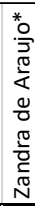 & JUMLAH \\
\hline \multicolumn{32}{|l|}{ Golongan yang terlibat } \\
\hline i) Guru & & * & & * & * & & & * & & * & & & * & * & * & * & * & & * & & & * & * & * & * & * & * & & & * & 19 \\
\hline ii) Pelajar & * & & * & * & * & * & * & & * & & * & * & & & & & & * & & * & * & & & & & & & * & * & & 14 \\
\hline iii) Pihak pentadbir dalam sekolah & & & & & & & & & & & & & & & & & * & & & & & & & & & & & & & & 1 \\
\hline iv) Pensyarah/Instruktor & & & & & & & & & & & & & & & & & & & & * & * & & & & & & & & & & 1 \\
\hline & & & & & & & & & & & & & & & & & & & & & & & & & & & & & & & \\
\hline \multicolumn{32}{|l|}{ Peringkat Pengajian } \\
\hline i) Sekolah rendah & & & & & & & & & & & & & & & & & & & & & & & & & & & & & & & 0 \\
\hline ii) Sekolah menengah & & * & & & & & & & & * & & * & * & * & * & & * & * & * * & * & * & * * & * & * & * & * & * & * & & * & 17 \\
\hline iii) Universiti & * & & * & * & * & * & * & * & * & & * & & & & * & * & & & & * & * & & * & & & & & & * & & 13 \\
\hline & & & & & & & & & & & & & & & & & & & & & & & & & & & & & & & \\
\hline
\end{tabular}

\section{Jenis skop kajian dan sifat-sifatpenggunaan flipped classroom}

Dalam tinjauan kajian ini, terdapat empat kategori yang berkaitan sifat-sifat persepsi penggunaan flipped classroom akan dibincangkan iaitu pencapaian dalam akademik, hubungan yang aktif dalam pembelajaran, persekitaran yang bersesuaian dan keberkesanan flipped classroom yang positif. 
Pengkaji akan membahagikan empat sifat yang telah dikategorikan kepada tiga bahagian iaitu kesan positif (+), kesan sederhana (=) dan kesan negatif (-). Berdasarkan jadual 5, data menunjukkan jenis skop kajian dan jenis sifat-sifat dalam penggunaan flipped classroom.

Berdasarkan jadual 5, skop kajian yang paling kerap dikaji oleh pengkaji lepas adalah persepsi tentang keberkesanan flipped classroom iaitu sebanyak 11 artikel daripada 30 artikel telah ditinjau. Daripada 11 artikel tersebut, terdapat lima keberkesanan yang positif dalam penggunaan flipped clsssroom. Menurut kajian Angela (2019) menunjukkan kesan yang positif dalam kalangan ibu bapa, guru-guru dan pelajar dalam penggunaan flipped classroom (Angela, 2019). Namun, terdapat 1 daripada 11 artikel yang menunjukkan kesan yang negatif ke atas penggunaan flipped classroom bahawa ketidakstabilan talian merupakan satu cabaran yang sukar diatasi semasa menggunakan kaedah flipped classroom. Skop kajian yang kedua adalah flipped classroom dapat mewujudkan hubungan yang aktif dalam pembelajaran iaitu 9 daripada 30 artikel yang ditinjau. Keputusan diperoleh bahawa terdapat 5 artikel yang memberikan kesan yang positif dalam pembelajaran kaedah flipped classroom, ini boleh mewujudkan hubungan yang aktif dalam kalangan pelajar, guru dan instruktor dan terdapat 1 artikel tidak bersependapat bahawa flipped classroom boleh mendorongkan pelajar supaya lebih aktif dalam pembelajaran. Manakala, terdapat 3 artikel yang menunjukkan bahawa tidak wujud perbezaan dengan penggunaan kaedah flipped classroom.

Berdasarkan rumusan ini, didapati bahawa skop kajian yang paling banyaki memberikan kesan yang positif adalah skop kajian (a) untuk mengenal pasti persepsi dalam pencapaian dalam akademik diikuti dengan skop kajian (b) dan (d) yang memberikan kesan yang positif iaitu hubungan aktif dalam pembelajaran dan keberkesanan dalam flipped classroom. skop kajian (c) yang menunjukkan tidak wujud perbezaan anatara persepsi dengan persekitaran yang bersesuaian.

Jadual 5: Senarai kajian lepas berdasarkan skop kajian

\begin{tabular}{|c|c|c|c|c|c|c|c|c|c|c|c|c|c|c|c|c|c|c|c|c|c|c|c|c|}
\hline Pengkaji/tahun & 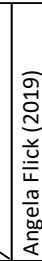 & 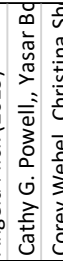 & 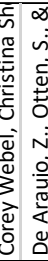 & 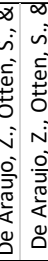 & & & 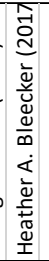 & & 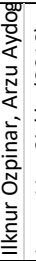 & & 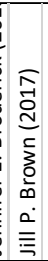 & 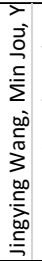 & & 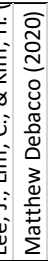 & 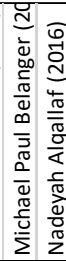 & & 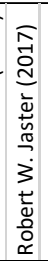 & 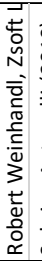 & 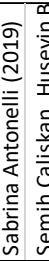 & & 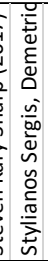 & 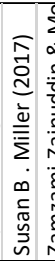 & 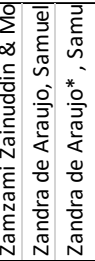 & JUMLAH \\
\hline & & & & & & & & & & & & & & & & & & & & & & & & \\
\hline \multicolumn{25}{|l|}{ Sifat-sifat penggunaan flipped classroom } \\
\hline a) pencapaian dalam akademik & & & $\mp$ & $\pm \mp$ & & & & & Е马 & & & $\mp$ & & & III & $\mp$ & & & & & $\mp$ & & & $7(+), 1(=)$ \\
\hline \multicolumn{3}{|c|}{ b) hubungan yang aktif dalam pembelajara } & & & & II & II & & & & II & & \pm & & 玉 & & & & I & & & \pm & & $5(+), 3(=), 1(-)$ \\
\hline c) persekitaran yang bersesuaian & & II & II & & & & & & & & & & & & & & III & & & & & & & $2(=)$ \\
\hline d) keberkesanaan flipped classroom & $\mp$ & & & & $\mp$ & & & $\mp$ & & $\mp$ & & 3 & E & II & & & & & III & III & & $I$ & $\Leftrightarrow(\Leftrightarrow)$ & $5(+), 5(=), 1(-)$ \\
\hline yang positif & & & & & & & & & & & & & & & & & & & & & & & & \\
\hline & & & & & & & & & & & & & & & & & & & & & & & & \\
\hline
\end{tabular}

\section{Kesimpulan}

Tinjauan sistematik yang dijalankan bertujuan untuk mengenal pasti persepsi dalam penggunaan flipped classroom. Oleh itu, tinjauan sistematik ini berfokus untuk menerangkan hubungan antara pemboleh ubah persepsi dalam penggunaan flipped classroom. Tiga aspek yang utama bagi pemboleh ubah persepsi penggunaan flipped classroom iaitu kemahiran, pengetahuan dan sikap. Pengkaji telah menggunakan empat pangkalan data iaitu ERIC (Education Resources information Centre), Science direct, PQDT open dan MYTO untuk mendapat artikel yang dikehendaki. Sebanyak 30 artikel yang menepati kriteria dan telah dianalisis. Hasil dapatan mendapati 5 artikel membuktikan terdapat kesan positif dan 1 artikel mencatatkan kesan negatif. Miller (2017) menyatakan pelajar kurang berinteraksi antara satu sama lain kerana terlalu tertumpu kepada perkakasan teknologi.

Bagi skop kajian yang kedua, adalah persepsi dalam pencapaian dalam akademik mencatatkan 7 artikel mencatatkan positif. Hal ini demikian dengan mengaplikasikan kaedah flipped classroom dapat 
peningkatan keputusan mereka dalam akademik. Menurut Nadeyah (2016) flipped classroom merupakan satu kaedah baharu dalam Pdp bagi subjek matematik untuk menangani masalah yang dihadapi kini.

\section{Rujukan}

A. Rahman, Azlina (2017). Kesan kaedah flipped classroom menerusi pembelajaran berasaskan projek ke atas pencapaian dan gaya pembelajaran pelajar. $\mathrm{PhD}$ thesis, Universiti Teknologi Malaysia, Faculty of Education.

Baytiyeh, H. (2017). The flipped classroom model: when technology enhances professional skills. International Journal of Information and Learning Technology, 34(1), 51-62. doi:10.1108/ijilt07-2016-0025

Berita Harian Online. Generasi digital perlu pedagogi abad ke-21. Dipetik pada 4 April pada https://www.bharian.com.my/rencana/muka10/2019/08/599377/generasi-digital-perlu-pedagogiabad-ke-21

Broderick, J. E. (2016). Providence, Rhode Island Doctoral Program in Educational Leadership John Hazen White College of Arts \& Sciences Flipped Classrooms as an Experiential Learning Strategy: How Do Faculty Adapt to Teaching with Instructional Technology?

Brown, J. P. (2017). Teachers' perspectives of changes in their practice during a technology in mathematics education research project. Teaching and Teacher Education, 64, 52-65. doi:10.1016/j.tate.2017.01.022

Buch, G. R. \& Vegas, L. (2017). The Flipped Classroom. Implementing Technology to Aid 10(2): 109116.

Caliskan, S., \& Bicen, H. (2016). Determining the Perceptions of Teacher Candidates on the Effectiveness of MOODLE Used in Flipped Education. Procedia Computer Science, 102, 654 658. doi: 10.1016/j.procs.2016.09.457

Chiam, C.C., Woo, T.K., Chung, H.T. and K.P. Nair, P.R.K. (2017). The behavioural intention to use video lecture in an ODL institution: Insights from learners' perspective. Asian Association of Open Universities Journal, 12(2), 206-217. https://doi.org/10.1108/AAOUJ-09-2017-0030

De Araujo, Z., Otten, S., \& Birisci, S. (2017). Mathematics teachers' motivations for, conceptions of, and experiences with flipped instruction. Teaching and Teacher Education, 62, 60-70.

Fatimah Hussain Alebrahin (2016). Implementation Evaluation Study: Flipped Classroom Professional Development with Faculty Members To Enhance Students' Engagement in Higher Education. Nothern Colorado University: Department of Educational Technology.

Hoda Baytiyeh (2017). The flipped classroom model: when technology enhances professional skills ", The International Journal of Information and Learning Technology, 34, 51 - 62 Permanent link to this document: http://dx.doi.org/10.1108/IJILT-07-2016-0025

Jaster, R. W. (2017). Student and Instructor Perceptions of a Flipped College Algebra Classroom 29(1): 1-16.

Kara Kamphuis. (2018). Teachers' Perceptions of the Use of AVID in the Math Classroom. Department of Teacher Education and Kinesiology College of Education and Heal.

Lee, J., Lim, C., \& Kim, H. (2017). Development of an instructional design model for flipped learning in higher education. Educational Technology Research \& Development, 65(2), 427e 453.

Matthew Debacco. (2020). Teachers' and administrators' perspectives on the flipped classroom: A qualitative study in a high school setting PHD Thesis, Ashford University.

Michael Paul B. (2018). Effects of Blended Learning and Gender on Mathematics Assessment in Elementary Fourth and Fifth Grade Students. Degree Doctor of Education Gra.

Powell, C. G., \& Bodur, Y. (2019). Teachers' perceptions of an online professional development experience: Implications for a design and implementation framework. Teaching and Teacher Education, 77, 19-30. doi: 10.1016/j.tate.2018.09.004

Sergis, S., Sampson, D. G., \& Pelliccione, L. (2018). Investigating the impact of Flipped Classroom on students' learning experiences: A Self-Determination Theory approach. Computers in

Human Behavior, 78, 368-378. doi: 10.1016/j.chb.2017.08.011 
Steven Kary Sharp (2017). Ipads In the Second Langauge Classroom: An Examination of Ipad Use By Teachers Through Tpack And Teacher Perception Lenses. PhD thesis, Univeristy of Libraries https://doi.org/10.13016/M2X05XF1D

Susan B. Miller B. S. (2017). Teachers' Use of Instructional Moves During Technology-Based Mathematical Activities. Chemical Engineering, University of Denver.

Wang, J., Jou, M., Lv, Y. \& Huang, C. (2018). Computers in Human Behavior An investigation on teaching performances of model-based fl ipping classroom for physics supported by modern teaching technologies. Computers in Human Behavior, 84, 36-48. doi: 10.1016/j.chb.2018.02.018

Webel, C., Sheffel, C., \& Conner, K. A. (2018). Flipping instruction in a fifth-grade class: A case of an elementary mathematics specialist. Teaching and Teacher Education, 71, 271282.doi:10.1016/j.tate.2018.01.007

Weinhandl, R., Lavicza, Z. \& Houghton, T. (2020). Mathematics and STEM teacher development for flipped education. Journal of Research in Innovative Teaching \& Learning. https://doi.org/10.1108/JRIT-01-2020-0006

Wong, T. M. 2018. Teaching innovations in Asian higher education. Perspectives of educators 13(2): 179-190. doi:10.1108/AAOUJ-12-2018-0032

Zainuddin, Z., \& Attaran, M. (2015). Malaysian students' perceptions of flipped classroom: a case study. Innovations in Education and Teaching International, 53(6), 660-670. doi:10.1080/14703297.2015.1102079 